\title{
YooJIn Koo
}

\section{A Configurative Approach to Conservative Mobilization in Japan: The Effect of Combining Political Opportunities and Threats}

In response to the growing popularity of conservative or right-wing movements around the world, this study explores the conditions under which Japanese conservatives are mobilized. It investigates five conditionspolitical opportunities and threats as political factors, grievance as an economic factor, and exclusionism and patriotism as cultural factorsand analyzes the combinations of these five conditions most favorable to the emergence of conservative movements in Japan. The results explicitly show that the mobilization of Japanese conservatives is strongly influenced by the political environment. This study sheds new light on: (1) the entanglement between the political milieu and the mobilization of conservatives in Japan; (2) political threats, in combination with political opportunities, that stimulate social mobilization; and (3) methodological challenges that may be managed through the use of QCA. This study could lead to further research that articulates the relations between political environments and conservative mobilization in Japan.

KEYWORDS: conservative movements in Japan, political opportunities, fsQCA, political threats

Yoojin Koo is Project Assistant Professor of East Asian Academy for New Liberal Arts (EAA) at the University of Tokyo. 
WE HAVE recently witnessed the growing presence of conservative or right-wing movements around the world, typically expressed as the growing popularity of extreme-right parties in European countries and rightwing movements in the US. In this regard, Japan is not exceptional. In particular, since the 1990s, conservative movements have become more conspicuous in the Japanese sociopolitical arena, ranging from movements advocating historical revisionism in textbooks, patriotic grassroots movements weighing in on national pride, and even racist movements notorious for hate speech. Taking these movements into account, this study investigates the factors that affect conservative mobilization and proposes a configurative approach to analyze the conditions under which conservative movements have emerged in post-Cold War Japan.

Previous research has argued that the emergence of conservative or right-wing forces has been influenced by (1) socioeconomic factors (e.g., the support of those who are economically disenfranchised), (2) cultural factors (e.g., groups that perceive immigrants as a threat), and (3) political factors (e.g., the rise of extreme-right parties). Research on Japan has offered two major explanations for individuals' identification with conservative or right-wing groups: (1) individuals are motivated by grievance and fear, in line with socioeconomic factors; and (2) individuals are motivated by nationalistic sentiment, a contention which also encompasses the cultural factors mentioned above.

Interestingly, unlike these two lines of argument, the question of political factors has received little attention in research on conservative movements in Japan, though it is alleged that there is a strong relationship between conservative movements and political factors or contexts. Thus, this study offers a systematic analysis of the political factors, and investigates the link between the two. In fact, it is crucial to consider this, when recalling that research on social mobilization has emphasized the relations between mobilization and its political milieu. For this, the study adopts the contention of political opportunities and political threats from literature on social movements, and their combination as proposed by Tilly (Tilly 1978; Goldstone and Tilly 2001).

In addition, this study attempts to articulate the configuration of combinations of conditions under which conservative movements emerge in Japan. In other words, while the existing research has focused on and

I wOulD LIKe to thank Yu Uchiyama, Rieko Kage, Takeshi Wada, Naoto Higuchi, two anonymous reviewers, and the editors for helpful and valuable comments. All the remaining shortcomings are the author's responsibility. 
measured the influence of the single factor (e.g., the net effect of one variable among cultural factors, such as the number of immigrants), this study rather articulates how each factor is woven together to generate conservative mobilization. That is, the combination of distinct factors is analyzed, such as the number of immigrants (a cultural factor), together with the unemployment rate (an economic factor). Despite the significance of measuring the net effect of one variable, research on right-wing movements has yielded results that often appear contradictory, such that the same factor (e.g., the number of immigrants) is verified in one study, but not in another. This suggests a different methodology may be in order. Towards this end, this study uses Qualitative Comparative Analysis (QCA) to explore the combinations of factors (conditions) that mobilize Japanese conservatives.

In this regard, this study investigates five conditions-political opportunities and threats as political factors, grievance as an economic factor, and exclusionism and patriotism as cultural factors-analyzing the combinations of these five conditions most favorable to the emergence of conservative movements in Japan. The results first show that a high level of either political opportunities or threats is necessary but trivial for the emergence of conservative movements in Japan, specifically from 1990 to 2012. Still, the analysis of sufficiency elucidates that the presence of political conditions proves to be decisive when combined with other conditions. Overall, the results explicitly indicate that the mobilization of Japanese conservatives is highly dependent on the political environment. This study sheds new light on: (1) the entanglement between political milieu and conservative mobilization in Japan; (2) political threats, in combination with political opportunities, as a means to stimulate social mobilization; and (3) the methodological challenges of using QCA. In what follows, this study first delineates what conservative movements in Japan look like, and then accounts for two general explanations in the existing scholarly literature, and makes a case for the necessity of an explanation based upon political context. Second, QCA analysis is used to illustrate the method, data, and operationalization. Finally, the findings and discussion will be addressed.

\section{Conservative Movements in Japan}

One might wonder about the usage of the term "conservative." There remains no consensus on how to label those who argue against immigration and integration, let alone those who affirm nativism or racism. In Europe, for example, political parties that are distinct from the established 
conservative parties have taken shape around anti-immigration policies. These parties have mobilized social forces opposed to immigration, and in this fashion have come close to gaining political power. As an academic compromise, most researchers studying the European context have labeled these parties "extreme right" or the "populist radical right" (MUDDE 2000; 2017). In Japan and the US, by contrast, such social forces are mobilized into vested, established "conservative" political parties, e.g., the Liberal Democratic Party (LDP) and the Republican Party, respectively.

It is important to bear in mind that both traditional conservative and radical right voters are blended and blurred in these established conservative parties, which poses a more complex reality for analysis. Equally important, this situation affects voters' self-consciousness as "conservatives," who see themselves as rational and ordinary, not as "extreme right wingers," who have a more radical, socially marginal, or violent image. In such a situation, a larger band of the political spectrum is encompassed, wherein people can sympathize with radical right movements. For the purpose of my argument, I shall adopt the term "conservative" in this study, while remaining mindful of its link to established conservative parties, and attempt to articulate what the choice of this term evokes in the context of Japanese conservative movements.

Who are they, then? In this study, I focus on the "Japan Conference" (Nippon Kaigi, hereafter NK), their activities and movements, representing conservative civil society in Japan (TAWARA 2016). This group enjoys the largest membership and number of local branches throughout Japan (about 40,000 members and 250 branches), so that it functions as a headquarters or platform to forge national conservative movements. NK was founded in 1997 through the merger of two major old-fashioned conservative groups, the "People's Council for the Protection of Japan" (Nippon o Mamoru Kokumin Kaigi, founded in 1981) and "Association for the Protection of Japan" (Nippon o Mamoru Kai, founded in 1974), taking the initiative in the realignment of Japanese conservative groups and movements. Its aim has been to raise a more unified voice, mainly for the revision of the Constitution, strong self-defense, patriotic education, national pride, and respect for Japanese traditions and history, especially those concerning the imperial household.

For this, NK expresses itself as a civil organization for policy proposals (advocacy) and national movements in order to recreate a "beautiful Japan" and to exhort Japanese people to have pride in their country. Towards this end, NK has developed annual action plans to vigorously drive nationwide movements. Their activities are summarized in FIGURE 1, 


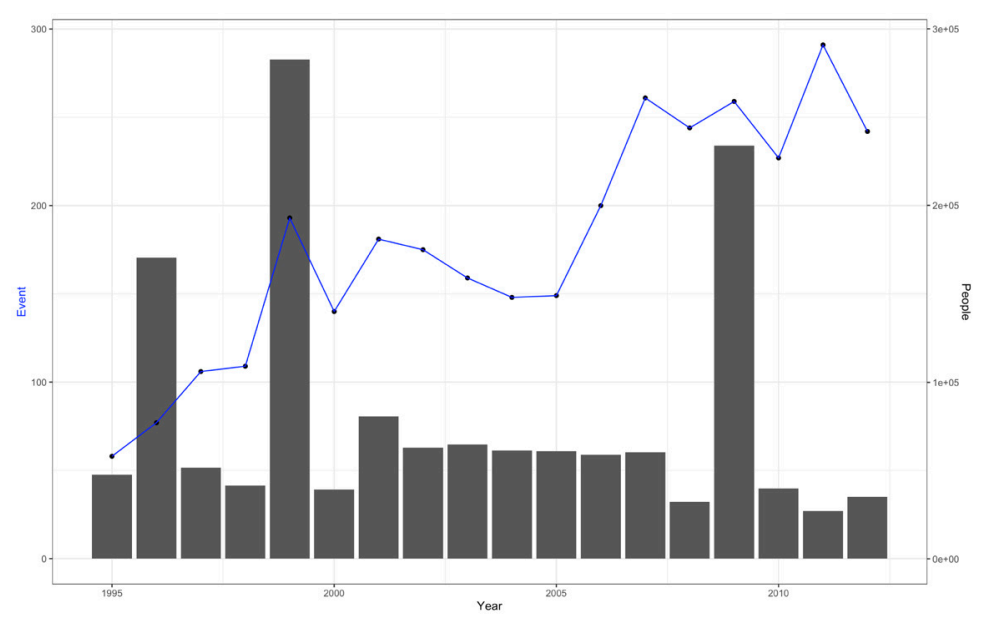

FIGURE 1. Number of Participants and Events of Conservative Civil Society. Source: JCED. Note: The line indicates the number of events.

which is based upon Japanese Conservative Event Data (JCED, created by the author; period: 1995-2012; total: 3,219 events; data source: Breath of Japan, NK's periodical). It indicates that the number of events in particular is gradually increasing over time, while the number of participants is fluctuating. In part, this is due to shortcomings in the event data set (e.g., the lack of information and missing values), and yet it is noteworthy that a large number of people were mobilized in 1999 and 2009 for commemorating the tenth and twentieth anniversaries of the enthronement of the emperor. This alone suggests that emperor-themed events might play a central role in mobilizing conservatives.

NK has played a pivotal role in the call for "Japan first (Japan as number one)," a strong nation, and for historical revisionism. In this regard, $\mathrm{NK}$ and conservative movements in general have gained visibility across Japan. Previous research on the growth of conservative movements in Japan has offered two primary explanations: (1) grievance and fear, and (2) nationalism.

\section{Explanation 1: Grievance and Fear}

Much like the consideration of socioeconomic factors in Western research, grievance and fear have been typically offered as primary explanations for the rise of conservative movements in Japan. That is, these movements have been driven by a sense of grievance and fear, understood as rooted 


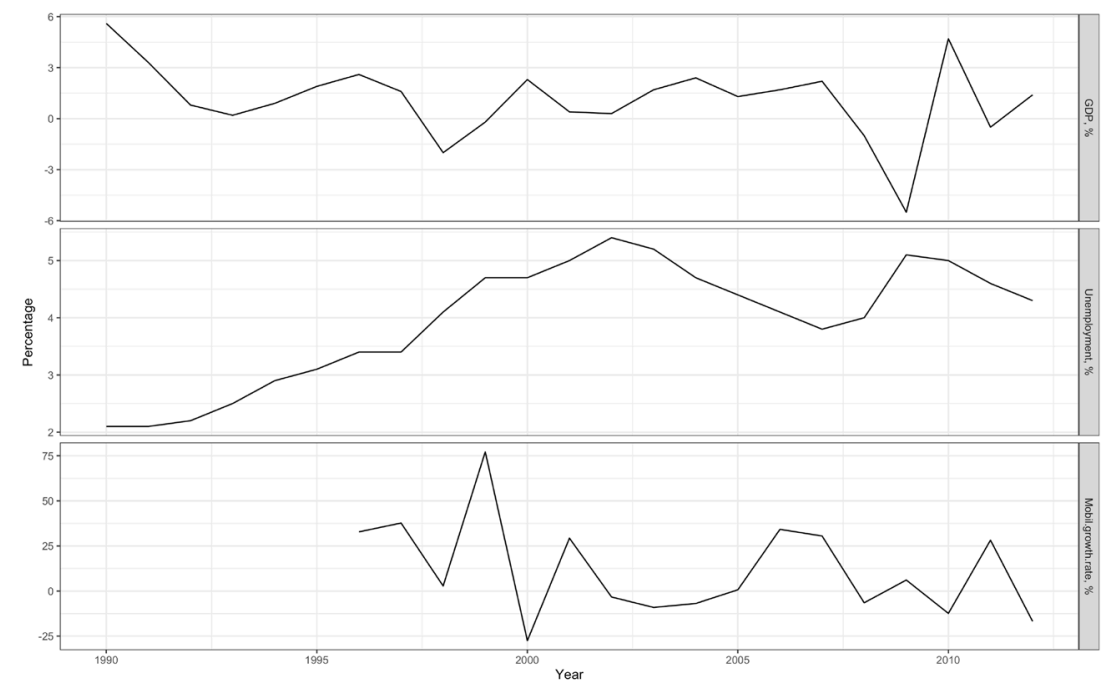

FIGURE 2. Economic Index and Comparison with the Growth Rate of Conservative Mobilization. Source: IMF; Mobil.growth.rate: growth rate of the number of conservative events from JCED.

in social and economic insecurity provoked by the effects of globalization. This explanation has been supported by research and journalistic writings on conspicuous events such as the historical revisionism of groups organizing and publishing history textbooks, which glorify wartime atrocities and wrongdoings, as well as the emergence of nativist or racist movements against Zainichi, Korean Japanese people (Oguma and Ueno 2003; YAsUDA 2012).

However, the criticism of this account has been that grievances are common, even omnipresent, and if it were the case that grievances generate movements, we would face a society filled with social movements (HIGU$\mathrm{CHI} 2014,50$ ). In addition, the literature on social movements has long argued that grievance and fear alone are not sufficient to trigger mobilization: rather, there needs to be a mechanism to mobilize grievances, such as well-financed organizations with effective leadership (MCCARTHY and ZALD 1977).

To elaborate on the socioeconomic dimensions of grievance and fear, FIGURE 2 indicates that these factors are only a partial explanation. In FIGURE 2, for example, which first indicates the principle economic index in Japan, GDP has repeatedly plunged to under zero percent while unemployment has increased gradually, which supports to some extent the 
explanation of grievance and fear in a macro-socioeconomic perspective. By contrast, when comparing between precarious economic indices and the growth rate of conservative mobilization from JCED (FIGURE 1), there is no consistent pattern, implying that there may be no correlation.

\section{Explanation 2: Nationalism}

The second predominant explanation has been that the growth of conservative movements in Japan is due to growing nationalism. Despite this, the explanation focused on nationalism has sophisticated causal paths extending beyond what is typically considered. First, this account is closely linked with that based upon grievance in that socioeconomic grievances such as a self-identification with the "losers" in society and a sense of competing with foreigners for jobs may find their expression in heightened nationalism, and second, deteriorating relations with neighboring countries based on historical revisionism helps to spread nationalism.

A second path is more distinctive, as is apparent when an emphasis on nationalistic sentiment in Japan is compared with the weight ascribed to cultural factors in Western-centered research (e.g., studies of the issue of Muslim immigration in Europe). Concerning the ideology of extremeright parties in Europe, Mudde emphasizes that nationalism is their core element (MUDDE 2000, 170, 175). He makes an intriguing point that it consists of a combination of internal homogenization, external exclusion, and ethic and state nationalism, but distinguishes it from historical revisionism vis-à-vis German roles in the Second World War and their legacy. For these reasons, I will give more attention to this second path of the argument for nationalism as a distinctive feature in Japanese conservative movements.

Offering a different explanation, some scholars have argued that the growing nationalism in Japan is associated with the broader dynamics of East Asian relations. HAsegawA and Togo (2008) assert that the collapse of the Cold War system in East Asia brought an ideological vacuum, and nationalism replaced it. For example, South Korea and China both witnessed struggles with communism, followed by greater economic growth and an increase in nationalistic sentiment. By contrast, Japan experienced several events-the end of the political stability of the so-called "1955 system" and the collapse of the bubble economy-that in turn affected the rise of a nationalism that stimulated conservative movements. Higuchi argues that Japan's relationship with its neighbors-especially South Korea-and the issue of historical revisionism has greatly influenced domestic xenophobia (Higuchi 2014, 204). 


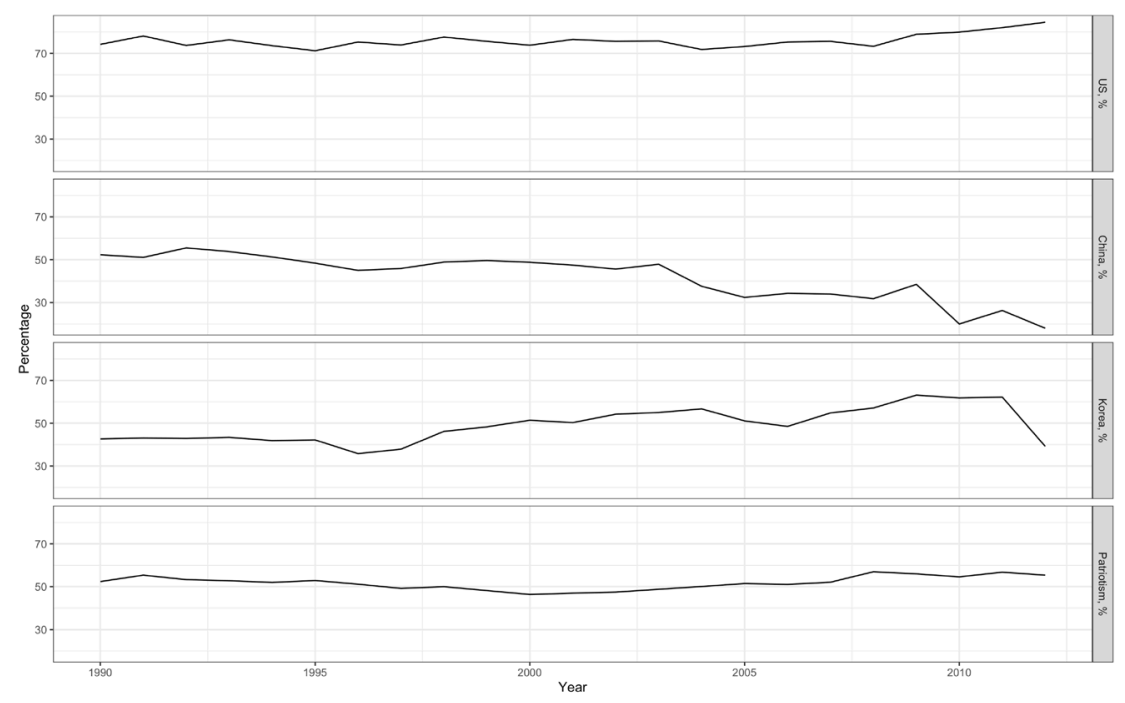

FIGURE 3. Degree of Amity with the US, China, and Korea, and the Degree of Patriotism. Source: Public Opinion Poll on Social Awareness conducted by the Cabinet Office.

However, this hypothesis concerning the influence of nationalism poses the issue of how we actually measure it. To illustrate, FIGURE 3 indicates how the degree of amity with neighboring countries fluctuates over time, whereas the degree of patriotism appears stable. Research on Japanese national identity also indicates a consistent degree of patriotism over time (TANABE 2010).

Taken together, these two primary explanations for the growth of conservative movements in Japan have both explanatory power and limitations. Notably, the lack of a clear correspondence between the national economic index and the growth rate of conservative mobilization, as well as the relatively consistent degree of patriotism lead us to seek an alternative or complementary explanation. Here, it is my contention that political factors deserve closer attention.

\section{Explanation 3: Political Opportunities and Political Threats}

Although there is a wealth of research on the political factors influencing the rise of the extreme-right parties outside of Japan, most notably in the European context, such analysis has rarely been conducted of conservative 
movements in Japan. To address this lacuna, I propose that we consider political factors in addition to the existing accounts described above.

A considerable number of published studies on social movements concern the relation between political environments and social mobilization. In this literature, the most popular argument invokes the theory of political opportunity structure. Simply put, the opening of a political opportunity means that a favorable change appears in the political environment-either institutionally, in terms of policy, or in the preferences of political elites - and this in turn facilitates social mobilization (EIsINGER 1973; Kitschelt 1986; Kriesi et. al. 1995; McAdam 1996; 1999; Tarrow 1998; Meyer 2004; Meyer and Minkoff 2004).

While the theory of political opportunity is widely used to account for political contention, critics have drawn attention to movements under conditions in which political opportunities (PO) are closed or absent (GOODWIN and JASPER 1999; JASPER 2011). This has led researchers to in turn consider political threats (PT), such as state repression. In fact, Tilly contends from the beginning that the opportunity for collective action has two sides-opportunity and threat-and makes clear that threats also stimulate mobilization (TILLY 1978). Tilly not only argues that threats function to stimulate mobilization, but provides the insight that the mobilizing effect of threats differs from that of opportunities, noting that "a given amount of threat tends to generate more collective action than the 'same' amount of opportunity," insofar as the "response to opportunity is likely to require more alteration of the group's organization and mobilization pattern than is [sic] response to threat; the group can respond to threat via its established routines" (Tilly 1978, 135).

In subsequent research, Goldstone and Tilly elaborate on this argument, referring to opportunity as "the probability that social protest actions will lead to success in achieving a desired outcome," and threats as "the costs that a social group will incur from protest, or that it expects to suffer if it does not take action," and they suggest different patterns that follow the specific ways in which "opportunity" and "threat" come together (GolDSTONE and Tilly 2001, 182-83). In light of this, they contend, "a group may also decide to risk protest (mobilization), even if opportunities seem absent, if the costs of not acting seem too great" (Goldstone and Tilly 2001,183 ). In other words, a high degree of threat combined with a sense of opportunity can generate mobilization. Using this argument as a point of departure, other researchers have elucidated the influence of threats on social mobilization, as well as taking their combination with opportunities 
into account (Almeida 2003; KARAPIN 2011; Alimi and Hirsch-Hoefler 2012; Ho 2015).

Researchers on right-wing movements have also called attention to factors in the political environment: i.e., both political opportunities and political threats. Prior research has explored institutional factors (e.g., electoral systems that employ proportional representation), party systems, and so forth, as political opportunities (ARZHEIMER and CARTER 2006; SMITH 2010), as well as policy threats, the opposition of government ideology, as political threats (VAN DyKe and Soule 2002; SKOCPOL and Williamson 2012; MARTIN 2013). Intriguingly, research on right-wing movements tends to put more weight on threats rather than opportunities. McVeigh, for example, asserts that the "underlying logic regarding causal processes (for right-wing mobilization) must be altered substantially" (MCVeIGH 2009, 8).

Drawing upon these debates, I propose to analyze political threats, and explore how the combination of opportunities and threats has affected conservative movements in Japan. As a way to approach the Japanese context, this study attempts to develop the conceptualization of opportunity and threat by defining and operationalizing. Thus, I would first define political opportunities following Tarrow's definition, i.e., they may be understood as "consistent-but not necessarily formal or permanentdimensions of the political environment that provide incentives for collective action by affecting people's expectations for success or failure," and define political threats as the "consistent dimensions of the political environment that provide incentives for collective action by affecting people's expectations that costs are higher than individual or public interests by not acting" (TARROW 1998, 76). These definitions are confined to the political dimensions of mobilization, for some critics have raised the concern that the concept of political opportunity is "in danger of becoming a sponge that soaks up virtually every aspect of the social movement environment" (GAMSON and MEYer 1996, 275).

In order to embody the concepts of political opportunity and threat (hereafter, PO and PT), I propose four political elements to construct PO and PT: (1) the ideology of the Prime Minister (PM); (2) governmental policy and guidelines $(\mathrm{G})$; (3) the alliance with political elites (E); and (4) international political factors (I). ${ }^{1}$ This study examines whether each polit-

1. These four political elements have been selected from the published literature on the conceptualization of political opportunity. McAdam notes that the following four dimensions are highly consensual: (1) the relative openness or closure of the institutionalized political system; (2) the stability or instability of that broad set of elite alignments that typically 
ical element works as a $\mathrm{PO}$ or $\mathrm{PT}-$ for example, in the first Abe cabinet, the ideology of the PM (PM index) works as a PO-and further discerns the combination of each political element as a PO or PT. By analyzing these elements together, this study articulates the influence of political factors on conservative mobilization in Japan.

\section{Method: Qualitative Comparative Analysis (QCA)}

As noted above, notwithstanding the explanatory power of socioeconomic, cultural, and political factors that previous literature has touched upon, the inconsistent research results concerning right-wing movements has troubled researchers (GOLDER 2003). In order to mitigate this problem and to better capture the configuration of factors, researchers have in recent years steadily adapted the method of QCA. Compared to traditional statistical analysis, which shows the net effect of variables, QCA, based on Boolean and set-theoretic approaches, rather aims to combine qualitative (small $\mathrm{N}$ case studies) and quantitative (large $\mathrm{N}$ studies) approaches, and delineates the causal combination, in which each variable (condition) is relational (RAGIN 2008; MARX, RiHOuX, and RAGIN 2014). Moreover, QCA accounts for equlifinality, which refers to various (combinations of) conditions reaching the same outcome, and conjunctural causation, which "draws out attention to the fact that conditions do not necessarily exert their impact on the outcome in isolation from one another, but sometimes have to be combined in order to reveal causal patterns" (SCHNEIDER and WAGEMANN 2012, 89). For this, QCA offers both necessary and sufficient conditions: a condition is necessary for an outcome if it is always present when the outcome occurs (i.e., the outcome is a subset of the cause), and a condition is sufficient for an outcome if the outcome always occurs when the condition is present (i.e., the cause is a subset of the outcome).

QCA also helps researchers to make coding decisions based on in-depth knowledge of each case. This characteristic is regarded as a great advantage of the QCA method, but has also raised concerns that they exhibit "a high degree of sensitivity to coding, ignore the relative strengths of independent variables and are logical in nature and thus exposed to great distortion in selection bias and data problem" (KROOK 2010, 891; LIEBERSON 2004). However, researchers using QCA have rebutted this criticism by

undergird a polity; (3) the presence or absence of elite allies; and (4) the state's capacity and propensity for repression (MCADAM 1996, 27). Meanwhile, Tarrow's five dimensions have been widely cited: (1) increasing access; (2) shifting alignments; (3) divided elites; (4) influential allies; and (5) repression and facilitation (TARrow 1998, 76-80). 
arguing that coding decisions are not made arbitrarily, but rather through substantial knowledge of each case, as well as through a careful dialogue between theory and evidence (KROOK 2010, 891).

With these advantages, the following points indicate that QCA is suitable for helping to understand the emergence of conservative movements in Japan. First, QCA can be applied for the systematic analysis of a moderate number of cases (e.g., this study examines twenty-three cases). Second, it appropriately shows the causal combinations of conditions. As we have seen, the account based upon grievance and nationalism only partially explains the rise of conservative movements. Similarly, the focus on nationalism only partially explains it. For this study, then, QCA appears an apt choice to explore causal combinations that are constituted by distinct conditions-i.e., grievance, nationalism, PO, and PT. Third, the method of QCA articulates necessary and sufficient conditions to analyze conservative movements.

Taking these advantages and concerns into consideration, this study will present the data, analysis, and findings by using QCA (with R) to examine the emergence of conservative movements in Japan.

\section{Data}

OUTCOME

This paper considers twenty-three cases of mobilization, which is the annual data of mobilization divided into two parts, with seven aspects in total (TABLE 1).

Calibration for the degree of membership of conservative mobilization is shown in a six-value fuzzy set-from $0,0.2,0.4,0.6,0.8$, to 1 ( 0 = fully out, $0.2=$ mostly but not fully out, $0.4=$ more or less out, $0.6=$ more or less in, $0.8=$ mostly but not fully in, $1=$ fully in $).{ }^{2}$ For final calibration, ichimannin taikai (ten thousand people assembly), signature drives, the foundation of major conservative groups, and other noteworthy events are considered most, because these activities are carried out most vigorously nationwide, and witnessed a greater mobilization of group resources,

2. Regarding the degree of membership, refer to RAGIN $(2008,31)$. In subsequent research, Ragin also suggests slightly different scores $-\mathrm{O}=$ fully out, $\mathrm{o.1}=$ mostly but not fully out, $0.4=$ more or less out, $0.6=$ more or less in, $0.9=$ mostly but not fully in, $1=$ fully in (RAGIN 2009, 91). As he explains that "the number of levels in fuzzy sets of this type is determined by the researcher," this paper adopts an earlier version of the six-value fuzzy set, for seven elements consisting of conservative mobilization are considered more independently and equally when calibrating. 
TABLE 1. Seven Aspects of Conservative Mobilization. Source: JCED.

\begin{tabular}{|c|c|}
\hline \multirow[t]{4}{*}{$\begin{array}{l}\text { MOBILIZING EVENTS/ } \\
\text { PEOPLE }\end{array}$} & $\begin{array}{l}\text { The number of events (and their growth rate, \%) held by NK } \\
\text { and conservative civil society }\end{array}$ \\
\hline & $\begin{array}{l}\text { The number of participants in events held by NK and con- } \\
\text { servative civil society }\end{array}$ \\
\hline & $\begin{array}{l}\text { ichimannin taikai (ten thousand people assembly) held by } \\
\text { NK at Nippon Budokan, a venue for national events, J-pop } \\
\text { concerts, entrance ceremonies, etc. }\end{array}$ \\
\hline & $\begin{array}{l}\text { Signature drives organized nationwide by NK and conserva- } \\
\text { tive civil society }\end{array}$ \\
\hline \multirow[t]{3}{*}{ ORGANIZING GROUPS } & The foundation of major conservative groups \\
\hline & The number of established NK local branches \\
\hline & The number of established women's groups in NK \\
\hline
\end{tabular}

when compared to other regular events. For example, during the period under analysis, NK and conservative civil society have held four ichimannin taikai in the Nippon Budokan, a large venue for national events or J-pop concerts. The events were, first, to celebrate the Coexistence of Asia in 1995 (though this event was originally intended to oppose the warrenouncing resolution commemorating the fiftieth anniversary of the end of the Second World War); second, to mobilize and celebrate two hundred thousand visits to Yasukuni Shrine in 2005; third, to oppose the revision of the Imperial Household Act, which allows women in the household to ascend to the throne; and fourth, to oppose granting voting rights to foreign residents. ${ }^{3}$ As for the massive, nationwide signature campaigns, they have lobbied for seven different issues over different periods: to oppose the war-renouncing resolution in the Diet from 1994 to 1995; to oppose the use of a separate (maiden) name for married women in 1995 and 2001; to oppose the establishment of a war memorial that would replace Yasukuni Shrine in 2002; to support a resolution to save Japanese nationals abducted by North Korea in 2002; to advocate the revision of the Fundamental Law of Education from 2004 to 2006; to oppose granting voting rights to foreign residents in 2010; and to call for the protection of the disputed

3. Although it is outside the period under analysis in this study, NK also held an ichimannin taikai in 2014, to advocate for the revision of the seventy-year-old Japanese Peace Constitution. 
TABLE 2. Conservative Mobilization Membership Score.

\begin{tabular}{|c|c|c|}
\hline MEMBERSHIP SCORE & DESCRIPTION & CASES \\
\hline 1 & Full mobilization & $1995,2005,2010$ \\
\hline 0.8 & $\begin{array}{l}\text { Most but not fully } \\
\text { mobilized }\end{array}$ & $\begin{array}{l}\text { 1994, 1997, 1999, 2002, 2004, } \\
2006\end{array}$ \\
\hline 0.6 & More or less mobilized & $\begin{array}{l}\text { 1996, 1998, 2001, 2007, 2009, } \\
\text { 2011, } 2012\end{array}$ \\
\hline 0.4 & $\begin{array}{l}\text { More mobilized than } \\
\text { not }\end{array}$ & $1993,2003,2008$ \\
\hline 0.2 & Mostly not mobilized & 1992,2000 \\
\hline $\mathrm{o}$ & Not mobilized & 1990,1991 \\
\hline
\end{tabular}

Senkaku Islands from 2010 to $2012 .{ }^{4}$ Finally, organizational changes have also been a typical focus of mobilization: e.g., the foundation of Atarashii Rekishi Kyokasho o Tsukurukai in 1996; Nippon Kaigi in 1997; Kitachosen ni Rachisareta Nihonjin o Kyushutsu Suru tame no Zenkoku Kyogikai (Sukuukai) in 1998; the fifth anniversary of the foundation of NK in 2002; and their tenth anniversary in 2007.5

Since the remaining elements are related to event data collected from 1995, the growth rate rather than the number itself is mainly considered as complementary. Again, the calibration has been carefully based on substantial research on conservative movements in each year, and selected by considering both between theory and evidence. Taken together, the degree of membership of mobilization and cases appears in TABLE 2.

\section{Causal Conditions}

\section{CONDITION 1: GRIEVANCE}

For the account based upon grievance and fear, the unemployment rate is adopted. Due to the fact that this account emphasizes economic or job insecurity, previous research has given greater attention to the unemployment rate among the various economic indices. Data is obtained from the IMF.

4. Beginning in 2014 and in addition to the ichimannin taikai, NK and conservative civil society have organized signature drives to gather support for the revision of the Constitution.

5. NK recently celebrated their twentieth anniversary in 2017. 
In order to calibrate the membership score of the unemployment rate in Japan from 1990 to 2012, a four-value fuzzy set of $0,0.33,0.67$, and 1 is adopted. Considering that an unemployment rate of 3 percent is regarded as nearing full employment, the membership score of grievance is calibrated as $O$ if it is less than 3 percent, 0.33 if the rate is between 3.1 to 4.1 , 0.67 if it is between 4.2 to 4.9 , and 1 if it is more than 5 percent. ${ }^{6}$

\section{CONDITIONS 2 AND 3: EXCLUSIONISM AND PATRIOTISM}

Given the complexity of the accounts based upon nationalism in the existing literature, this study separates the data concerned with nationalistic sentiment into two conditions: exclusionism and patriotism. For this analysis, this paper uses two indexes at hand: the degree to which Japanese do not feel amicable towards China for the condition of exclusionism, and the degree of patriotism for the condition of patriotism. ${ }^{7}$ Data is obtained from the Public Opinion Poll on Social Awareness conducted by the Japanese Cabinet Office. Similarly, a four-value fuzzy set is adopted for calibration. Assuming that a 60 percent opinion poll indicates a majority of

6. For setting these thresholds, I also used the density of data (Thiem and Dusa 2013, 30-31). There are two methods to calibrate: direct and qualitative (indirect or transformational) calibration (or assignment). Regarding qualitative calibration, QCA software (fsQCA or R) allows for calibrating the membership score using thresholds set by the researcher. Direct calibration or assignment, on the other hand, uses a suggested four- or six-value fuzzy set. The choice of this calibration strategy is also up to the researcher, which has little influence on the result. Schneider and Wagemann argue that "the general answer to this question is this: as long as the locations of the qualitative anchors are carefully chosen and thus not subject to changes in the calibration strategy or the functional form used in the semi-automated procedures, then the differences in set-membership scores will not be of major substantive importance" (SCHNEIDER and WAGEMAnN 2012, 38). This study also has found no major difference between two calibration strategies; accordingly, it adopts direct calibration for all conditions for simplicity.

7. As discussed in the literature review on the influence of nationalism, Japan's relations with Korea and China are likely to have an effect on the growth of conservative movements, i.e., as a thesis about exclusionism. Nevertheless, examining the relation between the degree to which Japanese people feel amicable toward China and Korea (FIgUrE 3), reveals a negative correlation $(r=-.468)$. The relation between the degree to which Japanese feel amicable toward China and the degree of patriotism shows a negative correlation $(r=-.471)$, whereas the relation between Korea and patriotism shows that they have nothing to do with each other $(r=.167)$. This study therefore determines that "China" and "patriotism" should be analyzed. This simple comparison provides a hint that the degree to which Japanese people feel amicable toward Korea is likely to be influenced by different factors. 
TABle 3. Four Political Elements, Data, and Examples.

\begin{tabular}{|c|c|c|}
\hline POLITICAL ELEMENTS & $\mathrm{PO}$ & PT \\
\hline $\begin{array}{l}\text { Prime Minister's Ideology, } \\
\text { (PM) } \\
\text { 1) LDP or not } \\
\text { 2) Policy speech } \\
\text { 3) PM's comments or speech } \\
\text { 4) Attitude toward Yasukuni }\end{array}$ & $\begin{array}{l}\text { PM } \\
\text { Conservative } \\
\text { 1) LDP } \\
\text { 4) Visits to Yasukuni } \\
\text { shrine }\end{array}$ & $\begin{array}{l}\text { pm } \\
\text { Liberal (progressive) } \\
\text { 1) DPJ and others } \\
\text { 3) Murayama Speech } \\
\text { 4) No visit to or com- } \\
\text { ments on Yasukuni }\end{array}$ \\
\hline $\begin{array}{l}\text { Governmental Policy, } \\
\text { Guidelines, and Comments, } \\
\text { (G) } \\
\text { 1) Constitution } \\
\text { 2) Education policy } \\
\text { 3) Diplomacy/security policy } \\
\text { 4) Historical issues } \\
\text { 5) Policies on "traditional } \\
\text { values" } \\
\text { 6) Cabinet members' state- } \\
\text { ments }\end{array}$ & $\begin{array}{l}\text { G } \\
\text { 1) Revision of the Con- } \\
\text { stitution } \\
\text { 2) Patriotic education } \\
\text { reform; guidelines for } \\
\text { school coursework } \\
\text { (reinforcing historical } \\
\text { issues) } \\
\text { 3) Collective self-defense } \\
\text { forces; hardline posi- } \\
\text { tion on China/Korea; } \\
\text { sanctions against } \\
\text { North Korea }\end{array}$ & $\begin{array}{l}\text { g } \\
\text { 1) Opposing revision of } \\
\text { the Constitution } \\
\text { 2) Guidelines for school } \\
\text { coursework to } \\
\text { consider neighboring } \\
\text { countries } \\
\text { 3) Expressing remorse } \\
\text { about past wrongdo- } \\
\text { ings } \\
\text { 5) Issue of separate sur- } \\
\text { names for the mar- } \\
\text { ried; voting rights } \\
\text { of foreign residents; } \\
\text { revision of Imperial } \\
\text { Household Law } \\
\text { 6) Kono speech; Chief } \\
\text { cabinet secretary's } \\
\text { meeting, e.g., of } \\
\text { establishing a new } \\
\text { memorial site }\end{array}$ \\
\hline $\begin{array}{l}\text { Alliance with Political Elites, } \\
\text { (E) }\end{array}$ & $\begin{array}{l}\mathrm{E} \\
\text { Conservative Diet mem- } \\
\text { bers' meetings }\end{array}$ & $\begin{array}{l}\text { e } \\
\text { Liberal Diet members' } \\
\text { meetings }\end{array}$ \\
\hline International Factors, (I) & $\begin{array}{l}\text { I } \\
\text { Favorable statements } \\
\text { by China/Korea/US; } \\
\text { amicable relations with } \\
\text { Taiwan }\end{array}$ & $\begin{array}{l}\text { i } \\
\text { Criticism by China/ } \\
\text { Korea/US }\end{array}$ \\
\hline
\end{tabular}


respondents, the membership score of the two conditions is calibrated as 0.33 if it is less than 50 percent, 0.67 if they are between 51 to 60 , and 1 if it is more than 61 percent.

CONDITIONS 4 AND 5:

POLITICAL OPPORTUNITIES AND POLITICAL THREATS

As noted above, this study attempts to express the concept of political opportunities and threats and their influence in conservative mobilization. TABLES 3 and 4 express the elements to formulate a PO, a PT, and the number of cases by their combinations.

Highlighting these four political elements, TABLE 3 shows how each element works as a political opportunity and threat. First, regarding the Prime Minister's ideology (PM), the following aspects are primarily considered: (1) whether the PM belongs to the LDP or not; (2) an annual policy speech addressed by the PM, or at the beginning of the Diet session; (3) other comments or speeches by the PM; and (4) the PM's attitude toward Yasukuni Shrine. For example, when the PM is from the LDP, the PM's policy speech or statements are favorable for conservative groups, and if the PM visits Yasukuni Shrine, then the PM element is regarded as a political opportunity (PO), expressed as "PM." On the contrary, if the PM does not belong to the LDP, or is from the progressive liberal party, and the PM delivers messages such as the Murayama Speech, which contained condolences and apologies for Japanese wartime atrocities, and if the PM explicitly mentions no visits to Yasukuni Shrine or makes no comments on the subject of Yasukuni, then the PM element is regarded as a political threat (PT), expressed as "pm."

In this way, the other three elements are treated and coded. First, each element is considered grounded on relevant research, and then is analyzed for whether it works as a PO or PT per each case (i.e., the year in this study).

As to how a PO and PT are scored in case-by-case fuzzy set membership, TABLE 4 presents the basic scoring guideline.

Taken altogether, TABLE 5 shows the final calibration of a PO and PT.

As we can see from TABLE 5, the QCA calibration requires in-depth knowledge of each case, and offers room for researchers to go back and forth between evidence and theory. 
44 | JAPANESE POLITICAL SCIENCE REVIEW 5 (2O20)

TABLE 4. Basic Scoring of PO and PT based on the Combination of Four Political Elements.

\begin{tabular}{|c|c|c|c|}
\hline $\begin{array}{c}\text { POLITICAL } \\
\text { OPPORTUNITY }\end{array}$ & & & \\
\hline $\begin{array}{l}\text { PM IS CONSERVATIVE } \\
(\mathrm{PM})\end{array}$ & SCORE & $\begin{array}{l}\text { POLITICAL THREAT } \\
\text { PM IS LIBERAL (PM) }\end{array}$ & SCORE \\
\hline $\mathrm{PM}^{\star} \mathrm{G}^{\star} \mathrm{E}^{\star} \mathrm{I}$ & 1 & $\mathrm{pm}^{\star} \mathrm{g}^{\star} \mathrm{e}^{\star} \mathrm{i}$ & 1 \\
\hline $\mathrm{PM}^{\star} \mathrm{E}^{\star} \mathrm{I}$ & 0.75 & $\mathrm{pm}^{*} \mathrm{e}^{*} \mathrm{i}$ & 0.75 \\
\hline $\mathrm{PM}^{\star} \mathrm{G}^{\star} \mathrm{I}$ & 0.75 & $\mathrm{pm}^{*} \mathrm{~g}^{\star} \mathrm{i}$ & 0.75 \\
\hline $\mathrm{PM}^{\star} \mathrm{G}^{\star} \mathrm{E}$ & 0.75 & $\mathrm{pm}^{\star} \mathrm{g}^{\star} \mathrm{e}$ & 0.75 \\
\hline$G^{\star} E^{\star} I$ & 0.75 & $g^{*} e^{*} i$ & 0.75 \\
\hline $\mathrm{PM}^{\star} \mathrm{G}$ & 0.5 & $\mathrm{pm}^{\star} \mathrm{g}$ & 0.5 \\
\hline $\mathrm{PM}^{\star} \mathrm{E}$ & 0.5 & $\mathrm{pm}^{\star} \mathrm{e}$ & 0.5 \\
\hline $\mathrm{PM}^{\star} \mathrm{I}$ & 0.5 & $\mathrm{pm}^{*} \mathrm{i}$ & 0.5 \\
\hline $\mathrm{G}^{\star} \mathrm{E}$ & 0.5 & $g^{*} e$ & 0.5 \\
\hline $\mathrm{G}^{\star} \mathrm{I}$ & 0.5 & $g^{\star} i$ & 0.5 \\
\hline$E^{\star} \mathrm{L}$ & 0.5 & $g^{\star} e$ & 0.5 \\
\hline PM & 0.25 & $\mathrm{pm}$ & 0.25 \\
\hline G & 0.25 & g & 0.25 \\
\hline E & 0.25 & $\mathrm{e}$ & 0.25 \\
\hline I & 0.25 & $\mathrm{i}$ & 0.25 \\
\hline- & $\mathrm{o}$ & - & o \\
\hline
\end{tabular}

Note: ${ }^{\star}$ is logical AND.

\section{Analysis and Findings}

A summary of the outcome and five conditions discussed above appears in TABLE 6.

\section{NECESSARY CONDITIONS FOR CONSERVATIVE MOBILIZATION IN} JAPAN

Recall that a necessary condition means that whenever the outcome is present, the condition is also present but its presence does not guarantee the outcome $(\mathrm{C} \geq \mathrm{O})$. Thus, an analysis of the necessary conditions (or combinations of conditions) indicates those which are present whenever conservative mobilization is present. Summarizing the results, TABLE 7 shows the necessary conditions for conservative mobilization in Japan. 
TABLE 5. Final Calibration of a PO and PT.

\begin{tabular}{|c|c|c|c|c|c|c|}
\hline No. & CASE & CABINET & PO & & $\mathrm{PT}$ & \\
\hline 1 & 1990 & $\begin{array}{l}\text { 89.08.10 } \\
\text { Kaifu Cab. }\end{array}$ & - & 0 & $(\mathrm{pm})$ & o \\
\hline 2 & 1991 & $\begin{array}{l}\text { 91.11.05 } \\
\text { Miyazawa Cab. }\end{array}$ & $\begin{array}{l}\text { G } \\
\text { (PKO law) }\end{array}$ & 0.25 & $\mathrm{pm}$ & 0.25 \\
\hline 3 & 1992 & Miyazawa Cab. & $\begin{array}{l}\text { G } \\
\text { (PKO law) }\end{array}$ & 0.25 & $\begin{array}{l}\mathrm{pm}^{*} \mathrm{i} \\
\text { (Emperor's visit to } \\
\text { China) }\end{array}$ & 0.5 \\
\hline 4 & 1993 & $\begin{array}{l}\text { 93.08.09 } \\
\text { Hosokawa Cab. }\end{array}$ & (E) & 0 & $\operatorname{pm}^{\star} \mathrm{g}^{\star}\left(\mathrm{e}^{\star} \mathrm{i}\right)$ & 0.75 \\
\hline 5 & 1994 & $\begin{array}{l}\text { 94.04.28 } \\
\text { Hata Cab. } \\
\text { 94.06.30 } \\
\text { Murayama Cab. }\end{array}$ & $\begin{array}{l}\text { G } \\
\text { (SP's sharp turn to } \\
\text { self-defense) }\end{array}$ & 0.25 & $\mathrm{pm}^{\star} \mathrm{g}^{\star}\left(\mathrm{e}^{\star} \mathrm{i}\right)$ & 0.75 \\
\hline 6 & 1995 & Murayama Cab. & $\mathrm{E}$ & 0.25 & $\begin{array}{l}\mathrm{pm}^{\star} \mathrm{g}^{\star} \mathrm{e}^{\star} \mathrm{i} \\
\text { (Murayama Speech) }\end{array}$ & 1 \\
\hline 7 & 1996 & $\begin{array}{l}\text { 96.01.11 } \\
\text { Hashimoto Cab. }\end{array}$ & $\mathrm{PM}^{\star} \mathrm{G}$ & 0.5 & $g^{*} e^{*} i$ & 0.75 \\
\hline 8 & 1997 & Hashimoto Cab. & $\mathrm{PM}^{*} \mathrm{G}^{\star} \mathrm{E}$ & 0.75 & $g^{*} \mathrm{i}$ & 0.5 \\
\hline 9 & 1998 & $\begin{array}{l}\text { 98.07.30 } \\
\text { Obuchi Cab. }\end{array}$ & $\mathrm{PM}^{\star} \mathrm{G}^{\star}(\mathrm{E})^{\star} \mathrm{I}$ & 0.75 & $\begin{array}{l}(\mathrm{pm})^{\star} \mathrm{g}^{\star} \mathrm{e}^{\star} \mathrm{i} \\
(\mathrm{JP} / \mathrm{KR}, \mathrm{JP} / \mathrm{CN} \text { partner- } \\
\text { ship agreement) }\end{array}$ & 0.75 \\
\hline 10 & 1999 & Obuchi Cab. & $\mathrm{PM}^{\star} \mathrm{G}^{\star}(\mathrm{E})^{\star} \mathrm{I}$ & 0.75 & $\mathrm{e}$ & 0.25 \\
\hline 11 & 2000 & $\begin{array}{l}\text { oo.04.05 } \\
\text { Mori Cab. }\end{array}$ & $\mathrm{PM}^{\star} \mathrm{G}^{\star}(\mathrm{E})^{\star} \mathrm{I}$ & 0.75 & - & o \\
\hline 12 & 2001 & $\begin{array}{l}\text { 01.04.26 } \\
\text { 1st Koizumi Cab. } \\
\end{array}$ & $\begin{array}{l}\mathrm{PM}^{\star} \mathrm{G}^{\star} \mathrm{E}^{\star} \mathrm{I} \\
\text { (Yasukuni visit, 9/11) }\end{array}$ & 1 & $(\mathrm{pm})^{*} \mathrm{~g}$ & 0.25 \\
\hline 13 & 2002 & 1st Koizumi Cab. & $\mathrm{PM}^{\star} \mathrm{G}^{\star} \mathrm{E}$ & 0.75 & $\begin{array}{l}(\mathrm{pm})^{\star} \mathrm{g}^{\star} \mathrm{e}^{\star} \mathrm{i} \\
(\text { New memorial facility, } \\
\text { Abductee issue) }\end{array}$ & 1 \\
\hline 14 & 2003 & $\begin{array}{l}\text { O3.11.19 } \\
\text { 2nd Koizumi Cab. }\end{array}$ & $\mathrm{PM}^{\star} \mathrm{G}^{\star} \mathrm{E}$ & 0.75 & $\mathrm{i}$ & 0.25 \\
\hline 15 & 2004 & 2nd Koizumi Cab. & $\mathrm{PM}^{\star} \mathrm{G}^{\star} \mathrm{E}$ & 0.75 & $(\mathrm{pm})^{\star} \mathrm{g}^{\star}(\mathrm{e})^{\star} \mathrm{i}$ & 0.75 \\
\hline 16 & 2005 & $\begin{array}{l}\text { 05.09.21 } \\
\text { 3rd Koizumi Cab. }\end{array}$ & $\mathrm{PM}^{\star} \mathrm{G}^{\star} \mathrm{E}^{\star}(\mathrm{I})$ & 1 & $\begin{array}{l}(\mathrm{pm})^{\star} \mathrm{g}^{\star} \mathrm{e}^{\star} \mathrm{i} \\
\text { (Yasukuni/ } \\
\text { Emperor issue) }\end{array}$ & 0.75 \\
\hline 17 & 2006 & $\begin{array}{l}\text { 06.09.20 } \\
\text { 1st Abe Cab. }\end{array}$ & $\begin{array}{l}\mathrm{PM}^{\star} \mathrm{G}^{\star} \mathrm{E}^{\star}(\mathrm{I}) \\
\text { (Fundamental Law of } \\
\text { Education) }\end{array}$ & 1 & $\begin{array}{l}\mathrm{g}^{\star} \mathrm{i} \\
\text { (Emperor issue) }\end{array}$ & 0.5 \\
\hline 18 & 2007 & $\begin{array}{l}\text { 07.09.26 } \\
\text { Fukuda Cab. }\end{array}$ & $\mathrm{PM}^{\star} \mathrm{G}^{\star} \mathrm{E}^{\star} \mathrm{I}$ & 1 & $\begin{array}{l}\mathrm{pm}^{\star} \mathrm{g}^{\star} \mathrm{i} \\
\text { (Fukuda Cab./ Comfort } \\
\text { women issue) }\end{array}$ & 0.75 \\
\hline 19 & 2008 & $\begin{array}{l}\text { o8.09.24 } \\
\text { Aso Cab. }\end{array}$ & $\mathrm{PM}^{\star} \mathrm{G}^{\star} \mathrm{E}$ & 0.75 & $(\mathrm{pm})^{\star} \mathrm{g}^{\star} \mathrm{i}$ & 0.5 \\
\hline 20 & 2009 & $\begin{array}{l}\text { o9.09.16 } \\
\text { Hatoyama Cab. }\end{array}$ & $(G)^{\star} E$ & 0.25 & $\mathrm{pm}^{\star} \mathrm{g}^{\star} \mathrm{e}^{*} \mathrm{i}$ & 1 \\
\hline 21 & 2010 & $\begin{array}{l}\text { 10.06.o8 } \\
\text { Kan Cab. }\end{array}$ & - & 0 & $\mathrm{pm}^{*} \mathrm{~g}^{*} \mathrm{e}^{*} \mathrm{i}$ & 1 \\
\hline 22 & 2011 & $\begin{array}{l}\text { 11.09.02 } \\
\text { Noda Cab. }\end{array}$ & $\begin{array}{l}\text { G } \\
\text { (Senkaku issue) }\end{array}$ & 0.25 & & 0.75 \\
\hline 23 & 2012 & Noda Cab. & $\begin{array}{l}(\mathrm{PM})^{\star} \mathrm{G}^{*} \mathrm{E} \\
\text { (2nd Abe Cab.) }\end{array}$ & 0.5 & & 0.75 \\
\hline
\end{tabular}

Note: Major issues are stated below in the combination of a PO and PT. A political element in parentheses implies that it is present but not influential. 
TABLE 6. Fuzzy-set Membership Scores of Outcome and Five Conditions.

\begin{tabular}{|c|c|c|c|c|c|c|}
\hline $\begin{array}{l}\text { YEAR } \\
\text { (CASE) }\end{array}$ & $\begin{array}{l}\text { CONSERVATIVE } \\
\text { MOBILIZATION }\end{array}$ & $\begin{array}{l}\text { POLITICAL } \\
\text { OPPORTUNI- } \\
\text { TIES }\end{array}$ & $\begin{array}{l}\text { Politi- } \\
\text { CAL } \\
\text { THREATS }\end{array}$ & $\begin{array}{l}\text { GRIEV- } \\
\text { ANCE }\end{array}$ & $\begin{array}{l}\text { EXCLUSION- } \\
\text { ISM }\end{array}$ & $\begin{array}{l}\text { PAtri- } \\
\text { OTISM }\end{array}$ \\
\hline 1990 & 0 & o & 0 & o & 0.33 & 0.67 \\
\hline 1991 & o & 0.25 & 0.25 & o & 0.33 & 0.67 \\
\hline 1992 & 0.2 & 0.25 & 0.5 & o & 0.33 & 0.67 \\
\hline 1993 & 0.4 & o & 0.75 & o & 0.33 & 0.67 \\
\hline 1994 & 0.8 & 0.25 & 0.75 & o & 0.33 & 0.67 \\
\hline 1995 & 1 & 0.25 & 1 & 0.33 & 0.33 & 0.67 \\
\hline 1996 & 0.6 & 0.5 & 0.75 & 0.33 & 0.67 & 0.67 \\
\hline 1997 & 0.8 & 0.75 & 0.5 & 0.33 & 0.67 & 0.33 \\
\hline 1998 & 0.8 & 0.75 & 0.75 & 0.33 & 0.33 & 0.67 \\
\hline 1999 & 0.6 & 0.75 & 0.25 & 0.67 & 0.33 & 0.33 \\
\hline 2000 & 0.2 & 0.75 & o & 0.67 & 0.33 & 0.33 \\
\hline 2001 & 0.6 & 1 & 0.25 & 1 & 0.33 & 0.33 \\
\hline 2002 & 0.8 & 0.75 & 1 & 1 & 0.33 & 0.33 \\
\hline 2003 & 0.4 & 0.75 & 0.25 & 1 & 0.33 & 0.33 \\
\hline 2004 & 0.8 & 0.75 & 0.75 & 0.67 & 0.67 & 0.67 \\
\hline 2005 & 1 & 1 & 1 & 0.67 & 1 & 0.67 \\
\hline 2006 & 0.8 & 1 & 0.5 & 0.33 & 1 & 0.67 \\
\hline 2007 & 0.6 & 1 & 0.75 & 0.33 & 1 & 0.67 \\
\hline 2008 & 0.4 & 0.75 & 0.5 & 0.33 & 1 & 0.67 \\
\hline 2009 & 0.6 & 0.25 & 1 & 1 & 0.67 & 0.67 \\
\hline 2010 & 1 & o & 1 & 1 & 1 & 0.67 \\
\hline 2011 & 0.6 & 0.25 & 0.75 & 0.67 & 1 & 0.67 \\
\hline 2012 & 0.6 & 0.5 & 0.75 & 0.67 & 1 & 0.67 \\
\hline
\end{tabular}

TABLE 7. Test of Necessary Conditions for Conservative Movements in Japan.

\begin{tabular}{|c|c|c|c|c|c|c|c|}
\hline CONDITION & CONSISTENCY & $\begin{array}{l}\text { RELEVANCE } \\
\text { OF NECESSITY } \\
\text { (RoN) }\end{array}$ & COVERAGE & COND. & CONSI. & RoN & cov. \\
\hline $\mathrm{PO}$ & 0.72 & 0.8 & 0.78 & po & 0.53 & 0.79 & 0.69 \\
\hline PT & 0.87 & 0.8 & 0.84 & pt & 0.4 & 0.8 & 0.6 \\
\hline GRE & 0.67 & 0.84 & 0.8 & gre & 0.56 & 0.73 & 0.65 \\
\hline EXC & 0.78 & 0.75 & 0.78 & exc & 0.47 & 0.82 & 0.68 \\
\hline PAT & 0.76 & 0.77 & 0.79 & pat & 0.59 & 0.89 & 0.83 \\
\hline
\end{tabular}

Note: The small letters indicate the negation of condition. 
In order to assess the strength of each combination, consistency and coverage are considered: consistency, like significance, is the degree to which the cases sharing a given combination of conditions agree in displaying the outcome, while coverage, like strength, is the degree to which a combination accounts for cases of an outcome. ${ }^{8}$ Bearing in mind that a condition is necessary only if it has a high consistency score-generally higher than 0.9-none of the conditions tested are necessary for a high level of conservative mobilization. But all of the conditions under consideration also show moderately high consistency scores, and it is worth noting that a PT in particular appears closest to the consistency threshold of 0.87 .

Meanwhile, the analysis of necessity relations can also be conducted with the combinations of conditions grounded carefully in theoretical arguments (EMMENEGGER 2011, 347). Investigating the political factors in conservative mobilization, this study tested the combination of $\mathrm{PO}+$ PT for necessity: the result notably reveals the highest consistency, 0.99, a high level of coverage, 0.76 , and a medium level of relevance, $0.55 .9^{9}$ This indicates that whenever we have the salient emergence of conservative mobilization in Japan, a high level of political opportunities, or political threats-or both-are present. This lends support to the argument that conservative mobilization is closely related to political milieu. Notwithstanding this high level of cut-off, the necessary conditions may turn out to be trivial; the relevance of necessity $(\mathrm{RoN})$ expresses whether the conditions are trivial or relevant. It therefore is also noteworthy that RoN is not sufficiently high to fully suggest $\mathrm{PO}+\mathrm{PT}$ as the necessary conditions for

8. Accordingly, it is likely to generate a combination that is highly consistent but low in coverage. Owing to this fact, there is a trade-off between consistency and coverage.

9. This result is obtained not only from theoretical assumptions but also from computation of necessity tests using the QCA package in R. Nineteen necessary conditions have been identified with a consistency cut-off of 0.9 and a coverage cut-off of 0.6 (SCHNEIDer and WAgemann 2012, 278; Thiem and Dusa 2013, 65). The results of nineteen combinations and tests with negated outcomes are available from the author upon request. Although PO + PT shows the highest consistency score, there are other combinations whose RoN or coverage score are higher than PO + PT, e.g., PT + pat (consi.: 0.96; RoN: 0.65; cov.: 0.79). However, noting that PT + PAT also appears with a fairly high level of such scores, and given that the need for careful design and consideration in the analysis of necessity based on both theory and an in-depth of knowledge of each case, this study only focuses on PO + PT. In fact, the combination PO + PT appears quite consistently in all tests for necessity. 


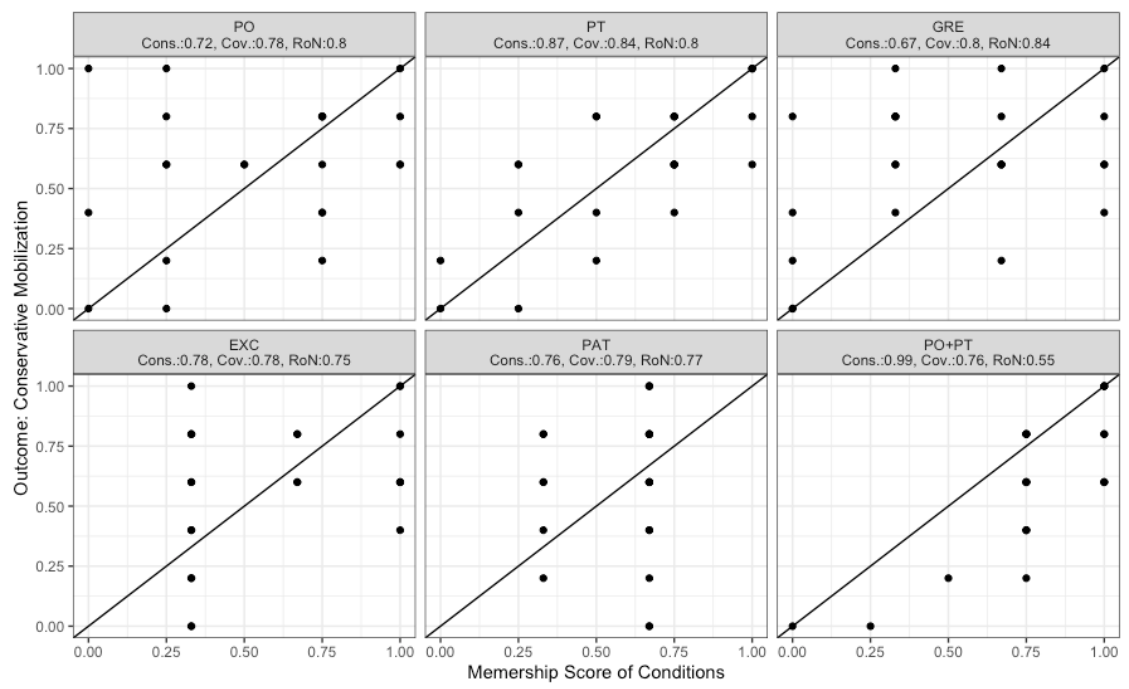

FIGURE 4. Necessity Plot $(\mathrm{C} \geq \mathrm{O})$.

TABle 8. Test of Sufficient Conditions for Conservative Movements in Japan (Intermediate Solution).

\begin{tabular}{lllll}
\hline & & & \\
CONFIGURATION & PO $^{*} \mathrm{PT}^{*} \mathrm{GRE}+$ & $\mathrm{PO}^{*} \mathrm{PT}^{\star} \mathrm{PAT}+$ & $\mathrm{PT}^{\star} \mathrm{GRE}^{*} \mathrm{EXC}^{*} \mathrm{PAT}+$ & $\begin{array}{c}\rightarrow \text { CONSERVATIVE } \\
\text { MOBILIZATION }\end{array}$ \\
\hline Consistency & 1.00 & 0.94 & 0.97 \\
PRI & 1.00 & 0.86 & 0.94 \\
Raw Coverage & 0.45 & 0.52 & 0.53 \\
Unique Coverage & 0.03 & 0.11 & 0.11 \\
Cases & $2002 ;$ & $1998 ;$ & $2009,2010,2011 ;$ \\
& 2004,2005 & $2007 ;$ & 2004,2005 \\
\hline Solution Consistency & 0.93 & 2004,2005 & \\
Solution PRI & 0.87 & & \\
Solution Coverage & 0.67 & & \\
\hline
\end{tabular}

Note: ${ }^{*}$ is logical AND. + is logical OR. PRI indicates proportional reduction in inconsistency; raw coverage measures how much of the outcome is covered, and unique coverage measures the proportion of membership in the outcome explained solely by each individual solution term. Cases from the same configuration are separated by a comma, those from different configurations by a semicolon. 
Japanese conservative movements. ${ }^{10}$ FIGURE 4 shows the necessity plot: we can see that cases of PO + PT fall below or onto the main diagonal compared to other unilateral conditions.

\section{Sufficient Configuration of Conditions for Conservative Mobilization in Japan}

Lastly, given the analysis of necessary conditions, this paper explores the sufficient conditions for conservative mobilization (typically, sufficient combinations of conditions). A sufficient condition refers to a condition, which, whenever it is present, the outcome is also present $(\mathrm{C} \leq \mathrm{O})$. In fact, the ultimate goal of QCA is to analyze set-theoretic sufficiency relations, for which constructing the truth table (consisting of 1 , present, and o, absent) is central (RAGIN 2009, 110). By analyzing the truth table, it yields three solutions: complex, parsimonious, and an intermediate solution. ${ }^{11}$ In this analysis, I focus on and discuss the intermediate solution, in which the logical remainders designated by a researcher grounded on theories are incorporated into the solution. ${ }^{12}$ For an intermediate solution, I assume that present all conditions, conservative mobilization is stimulated, as previous research has emphasized their presence. The result is shown as follows:

$\mathrm{PO}^{\star} \mathrm{PT}^{\star} \mathrm{GRE}+\mathrm{PO}^{\star} \mathrm{PT}^{\star} \mathrm{EXC}^{\star} \mathrm{PAT}+\mathrm{PT}^{\star} \mathrm{GRE}^{\star} \mathrm{EXC}{ }^{\star} \mathrm{PAT} \rightarrow$ Conservative Mobilization

10. The trivialness of $\mathrm{PO}+\mathrm{PT}$ is incurred from which $\mathrm{X}$ is much larger than $\mathrm{Y}$ (SCHNEIDER and WAGEMANN 2012, 233). However, it can be also interpreted such that the political environment is an overarching contextual factor, which is in line with my argument.

11. Each solution is presented based on a different treatment of the "remainder" combination, meaning "a logically possible combination of conditions lacking empirical instances (or cases)” (RAGIN 2008, 131). A complex solution is given when no logical remainders are used, a parsimonious solution when logical remainders are used without evaluating their plausibility, and an intermediate solution when logical remainders are restricted to those that are most plausible (RAGIN 2009, 118).

12. A raw consistency threshold is set by o.8. Ragin and Schneider as well as Wagemann suggest it above 0.75 (RAGIN 2009, 118; SCHNEIDER and WAGEMANN 2012, 279), but in this analysis there is a gap in consistency between two groups of rows, so that 0.8 is decided as a clear dividing line for two groups. Again, all data and results are available from the author upon request. Refer to the appendix for the results of complex and parsimonious solutions, and of an intermediate solution with a negated outcome. In particular, the result of an intermediate solution with a negated outcome helps reinforce the robustness of this study's results, in that the presence of conditions does not generate the absence of outcome, i.e. contradictory cases. 
The solution shows a high level of consistency (0.93), and a moderate level of coverage (0.67). It also presents the features of equifinality and conjunctural causation noted earlier. It identifies three causal paths to conservative mobilization in Japan. Three causal paths are highly consistent and sufficient conditions for the outcome. The first causal path is a combination of the presence of political opportunities and threats, along with grievances. The second causal path similarly offers the combination of the presence of political opportunities and threats, along with patriotism. These two solutions cover five cases: 1998, 2002, 2004, 2005, and 2007 (two multiple-covered cases). These years indicate mostly events held during the Obuchi administration, the Koizumi administration, and the transition period from the first Abe administration to the Fukuda administration. Under these administrations, conservative mobilization has a causal path either of $\mathrm{PO}^{\star} \mathrm{PT}^{\star} \mathrm{GRE}$ or of $\mathrm{PO}^{\star} \mathrm{PT}^{\star} \mathrm{PAT}$. Notably, the posture of these administrations works as both political opportunities and threats.

Taking these causal paths into account, we can explain the movement in 2002. For example, PM Koizumi's cabinet communicated a high level of both PO and PT; continued visits to Yasukuni Shrine, and references to a revision of the Fundamental Law of Education worked as PO, while Koizumi's speech expressing condolence and apologizing for Japan's wartime atrocities, his stance on forming an Advisory Committee to review a new war memorial facility replacing Yasukuni, and his visit to North Korea can be understood as PT. Along with PO and PT, there was also a high level of unemployment (5.4 percent). These three conditions combined to generate a vigorous conservative mobilization, such as the movement to advocate the PM's Yasukuni visit, and to simultaneously oppose a new war memorial facility through a nationwide signature campaign and the organization of several big assemblies to specifically oppose a new war memorial facility. ${ }^{13}$

The third causal path is the combination of four conditions except for $\mathrm{PO}-\mathrm{PT}^{\star} \mathrm{GRE}^{\star} \mathrm{EXC}^{\star} \mathrm{PAT}-$ to explain the mobilization in 2004, 2005, 2009, 2010, and 2011. This coincides with the period during which the Democratic Party of Japan (DPJ) governed Japan (without the multiplecovered cases). Under the DPJ administration, political opportunities were rare. As one of the chief staff members of NK described it, Japan was

13. Between June and December of 2002, JCED shows four big assemblies in Tokyo. Coorganized with Eireini Kotaerukai, Shusho ni Yasukuni Jinja Sanpai o Motomeru Kokumin no Kai, and Yasukuni Diet members' group, NK mobilized about eight thousand participants. 
"approaching the era of a very cold winter and a backlash" (Breath of Japan [NK's periodical] 2007). Among the political threats, an explicit policy statement against visits to Yasukuni, a review of the option to build a new war memorial, the East Asian Community Initiative, the transfer of the US military base at Futenma in Okinawa, a decision on granting voting rights to foreign residents, support for a separate surname for married womenall of these are present. In addition to a high level of political threats, grievances are also present, such as the unemployment rate again reaching 5 percent, deteriorating relations with China around the dispute over the Senkaku islands, and furthermore about 80 percent of Japanese responded that they do not feel amicable toward China. Lastly, the degree to which Japanese people feel proud of their nation reached almost 60 percent. Under this combination of conditions, conservative movements emerged, specifically movements focused on the opposition to grant voting rights to foreign residents, opposition to the recognition of separate surnames for married women, and support for protecting Japan's territory and seas.

The description and interoperation detailed above can be also summarized as $\mathrm{F} 1$.

F1: $\mathrm{PO}^{\star} \mathrm{PT}^{\star}(\mathrm{GRE}+\mathrm{PAT})+\mathrm{PT}^{\star} \mathrm{GRE}^{\star} \mathrm{PAT} \rightarrow$ Conservative Mobilization

All in all, there are three distinctive features derived from QCA analysis. The first salient point is that a combination of conditions of political opportunity and threat appear in most solutions. It indicates that a political environment shaped by a combination of political opportunities and threats are decisive for Japanese conservative movements. Second, most notably, political threats appear in every solution (see F2, below, for details).

F2: $\mathrm{PT}^{\star}\left(\mathrm{PO}^{\star} \mathrm{GRE}+\mathrm{PO}^{\star} \mathrm{PAT}+\mathrm{GRE}^{\star} \mathrm{EXC}^{\star} \mathrm{PAT}\right) \rightarrow$ Conservative Mobilization

$\mathrm{F}_{2}$ in particular offers a hint that $\mathrm{PT}$ can be a necessary condition for conservative mobilization in Japan, but we have already checked it is not; PT has almost reached the 0.9 consistency threshold in the analysis of necessity. Notwithstanding, this result explicitly shows that the presence of PT plays a decisive role in the emergence of Japanese conservative movements. It also squares with existing research on conservative or right-wing movements in that analysis of political threats shows that they have a mobilizing effect that is sometimes greater than that of political opportunities.

These two points, namely the combination of political opportunities and threats, and the presence of political threats, suggest some significant 
implications for the theory of political opportunity. As discussed earlier, the theory of political opportunity has offered a substantial contribution to the field by exploring contextual political influences on social mobilization. At the same time, though, it has been criticized insofar as it allows little leeway for other explanations. As another approach to contextual political factors, researchers have called attention to political threats and their combination with political opportunities. In effect, the reality surrounding mobilization is more dynamic, and this result indicates one of the attempts to account for the significance of the milieu combining political opportunities and threats in a democratic society. ${ }^{14}$

In relation to this, insofar as PT marks slightly higher scores than political opportunities in both necessity and sufficiency analyses-implying its more encompassing impact on social mobilization - the role of PT should be highlighted. In democratic societies, political threats, typically political alteration and policy threats, sometimes invoke greater mobilization than any other conditions that political opportunities create. In this regard, PT has played a pivotal role in the mobilization of Japanese conservatives since the 1990 .

Last but not least, the results show that although the other three aforementioned conditions (i.e. grievance, exclusionism, and patriotism) doubtless bear some influence, it is noteworthy that while previous research has argued for a single condition determining conservative mobilization, this study reveals that they become influential only in combination with specifically political factors, e.g., PO or PT. Stated differently, a more thorough analysis indicates that grievance and nationalism may be understood less as direct influences, as they are more commonly mobilized through political maneuvering.

\section{Conclusion}

In response to the growing popularity of conservative or right-wing movements around the world, this study has explored the conditions under which Japanese conservatives are mobilized. For this, factors in the political environment are analyzed. While political factors have been a subject of scholarly discussion in other contexts, they have not been given sufficient attention as a means to explain the mobilization of Japanese con-

14. Still, we can find more complex mechanisms behind the scenes. Karapin has attempted to untangle the dynamics (in fact, it is described as a "spiral") of political opportunities and threats with eight mechanisms with twenty-two arrows in democratic settings (KARAPIN 2011). 
servatives. By exploring and utilizing the theory of political opportunity as it has been discussed in prior studies of social movements, this study simultaneously sheds light on the significance of political threats, and the combination of political opportunities and threats to stimulate social mobilization in Japan.

Although the mobilization of conservatives has generally been explained using appeals to grievance and nationalism, the results of these analyses have been inconsistent and their explanatory powers thus appear limited. Hence, the present study takes a configurative approach using the method of QCA. A detailed analysis of five conditions-political opportunity, political threats, grievance, exclusionism, and patriotism-strongly supports the influence of political factors. The results explicitly show that the mobilization of Japanese conservatives is strongly influenced by the political environment during the period this study covers. This study contributes to shed new light on: (1) the entanglement between the political milieu and the mobilization of conservatives in Japan; (2) political threats, in combination with political opportunities, stimulate social mobilization; and (3) methodological challenges may be managed through the use of QCA.

Regardless of these findings and their implications, this study has some limitations, which leave room for further research. In particular, regarding the period of cover, the present analysis does not aptly consider conservative movements in the 1990s. Insofar as the 1990s were a transitional period for conservative movements (e.g., in 1995, there were organizational realignments and massive opposition movements were organized against a government resolution renouncing war), it is fair to say this period was empirically pivotal (Koo 2018). This implies that different causal pathways existed in the 1990 s from those at play under rule by the DPJ, even though they both create seemingly similar environments dominated by political threats. A more extended analysis of this decade may suggest another driving force to influence the mobilization of conservatives.

Considering that Japanese conservative movements should be understood more in relation to their political contexts, future research identifying the relation between conservative movements and political factors should be more elaborated in multifaceted perspectives. 


\section{Appendix}

APPENDIX 1. Complex Solution.

\begin{tabular}{|c|c|c|c|c|c|}
\hline CONFIGURATION & CONSISTENCY & PRI & $\begin{array}{l}\text { RAW } \\
\text { COVERAGE }\end{array}$ & $\begin{array}{l}\text { UNIQUE } \\
\text { COVERAGE }\end{array}$ & CASES \\
\hline $\mathrm{PO}^{\star} \mathrm{PT}^{\star}$ gre $^{\star} \mathrm{PAT}$ & 1.00 & 0.81 & 0.38 & 0.11 & $1998 ; 2007$ \\
\hline$+\mathrm{PT}^{\star} \mathrm{GRE}^{\star} \mathrm{EXC}^{\star} \mathrm{PAT}$ & 1.00 & 0.94 & 0.53 & 0.18 & $\begin{array}{l}2009,2010, \\
2011 ; \\
2004,2005\end{array}$ \\
\hline \multirow[t]{2}{*}{$+\mathrm{PO}^{*} \mathrm{PT}^{*} \mathrm{GRE}^{*}$ exc $^{*}$ pat } & 0.45 & 1.00 & 0.24 & 0.02 & 2002 \\
\hline & 0.03 & 0.87 & 0.66 & & \\
\hline
\end{tabular}

APPENDIX 2. Parsimonious Solution.

$\mathrm{M} 1: \mathrm{PO}^{\star} \mathrm{PT}+(\mathrm{EXC}) \rightarrow \mathrm{OUTCOME}$

$\mathrm{M} 2: \mathrm{PO}{ }^{\star} \mathrm{PT}+\left(\mathrm{PT}^{\star} \mathrm{GRE}\right) \rightarrow$ OUTCOME

\begin{tabular}{|c|c|c|c|c|c|c|c|}
\hline CONFIGURATION & $\begin{array}{l}\text { CONSIS- } \\
\text { TENCY }\end{array}$ & PRI & $\begin{array}{l}\text { RAW } \\
\text { COVERAGE }\end{array}$ & $\begin{array}{l}\text { UNIQUE } \\
\text { COVERAGE }\end{array}$ & (M1) & (M2) & CASES \\
\hline $\mathrm{PO}^{*} \mathrm{PT}$ & 0.92 & 0.88 & 0.60 & 0.04 & 0.07 & 0.16 & $\begin{array}{l}2007 ; 2002 \\
2004,2005\end{array}$ \\
\hline+ EXC & 0.78 & 0.63 & 0.78 & 0.10 & 0.24 & & $\begin{array}{l}2009,2010, \\
2011 ; \\
2007 ; 2004, \\
2005\end{array}$ \\
\hline$+\mathrm{PT}^{\star} \mathrm{GRE}$ & 0.92 & 0.85 & 0.59 & 0.00 & & 0.14 & $\begin{array}{l}2009,2010, \\
2011 ; \\
2002 ; 2004, \\
2005\end{array}$ \\
\hline $\mathrm{M}_{1}$ & 0.79 & 0.67 & 0.85 & & & & \\
\hline $\mathrm{M} 2$ & 0.89 & 0.81 & 0.76 & & & & \\
\hline
\end{tabular}

APPENDIX 3. Intermediate Solution (Negated Outcome).

\begin{tabular}{lllll}
\hline CONFIGURATION & CONSISTENCY & PRI & $\begin{array}{l}\text { RAW } \\
\text { COVERAGE }\end{array}$ & $\begin{array}{l}\text { UNIQUE } \\
\text { COVERAGE }\end{array}$ \\
\hline $\mathrm{PO}^{*} \mathrm{PT}^{\star} \mathrm{GRE}$ & 0.60 & 0.00 & 0.39 & 0.00 \\
$+\mathrm{PO}^{*} \mathrm{PT}{ }^{*} \mathrm{PAT}$ & 0.61 & 0.12 & 0.50 & 0.11 \\
$+\mathrm{PT}^{\star} \mathrm{GRE}^{\star} \mathrm{EXC}^{\star} \mathrm{PAT}$ & 0.53 & 0.00 & 0.42 & 0.03 \\
\hline
\end{tabular}




\section{REFERENCES}

Alimi, Eitan Y., and Sivan Hirsch-HoEfler

2012 "Structure of Political Opportunities and Threat, and Movement-Countermovement Interaction in Segmented Composite Regimes." Comparative Politics 44/3: 331-49.

Almeida, Paul D.

2003 "Opportunity Organization and Threat-Induced Contention: Protest Waves in Authoritarian Settings.” American Journal of Sociology 109/2: 345-400.

Arzheimer, Kai, and Elisabeth Carter

2006 "Political Opportunity Structures and Right-Wing Extremist Party Success." European Journal of Political Research 45: 419-43.

EISINGER, Peter K.

1973 "The Conditions of Protest Behavior in American Cities." American Political Science Review 67/1: 11-28.

EMmeneGger, Patrick

2011 "Job Security Regulations in Western Democracies: A Fuzzy Set Analysis." European Journal of Political Research 50: 336-64.

Gamson, William A., and David S. Meyer

1996 "Framing Political Opportunity." In Comparative Perspectives on Social Movements: Political Opportunities, Mobilizing Structures, and Cultural Framings, Doug McAdam, John McCarthy, and Mayer N. Zald, eds., 275-90. Cambridge: Cambridge University Press.

Golder, Matt

2003 "Explaining Variation in the Success of Extreme Right Parties in Western Europe." Comparative Political Studies 36/4: 432-66.

Goldstone, Jack A., and Charles Tilly

2001 "Treat (and Opportunity): Popular Action and State Response in the Dynamics of Contentious Action." In Silence and Voice in the Study of Contentious Politics, Ronald R. Aminzade et al., eds., 179-94. Cambridge: Cambridge University Press.

Goodwin, Jeff, and James M. JAsPer

1999 "Caught in the Winding, Snarling Vine: The Structural Bias of Political Process Theory." Sociological Forum 14/1: 27-54.

Hasegawa, Tsuyoshi, and Kazuhiko Togo, eds.

2008 East Asia's Haunted Present: Historical Memories and the Resurgence of Nationalism. Santa Barbara, CA: Praeger Security International.

Higuchi Naoto

2014 Nihongata haigaishugi (The Japanese-Model of Xenophobic Exclusionism). Nagoya: Nagoya University Press. 
Ho, Ming-sho

2015 "Occupy Congress in Taiwan: Political Opportunity, Threat, and the Sunflower Movement." Journal of East Asian Studies 15: 69-97.

JASPER, James M.

2011 "Introduction: From Political Opportunity Structures to Strategic Interaction." In Contention in Context: Political Opportunities and the Emergence of Protest, Jeff Goodwin and James M. Jasper, eds., 1-34. Palo Alto, CA: Stanford University Press.

KARAPIN, Roger

2011 "Opportunity/Threat Spirals in the U.S. Women's Suffrage and German Anti-Immigration Movements." Mobilization 16/1: 65-80.

Kitschelt, Herbert P.

1986 "Political Opportunity Structures and Political Protest: Anti-Nuclear Movements in Four Democracies." British Journal of Political Science 16: $57-85$.

Koo Yoojin

2018 "Nihon ni okeru seijiteki kyoi to hoshu undo: 1990 nendai no fusen ketsugi hantai undo o chushin ni" (Political Threats and Conservative Movements in Japan: Focusing on the Movement Opposing the WarRenouncing Resolution in the 1990s). Journal of East Asia Area and Culture 14: 26-54.

Kriesi, Hanspeter, Ruud Koopmans, Jan Willem DuyvendaK, and Marco G. Giugni

1995 New Social Movements in Western Europe: A Comparative Analysis. Minneapolis: University of Minnesota Press.

Krook, Mona Lena

2010 "Women's Representation in Parliament: A Qualitative Comparative Analysis.” Political Studies 58: 886-908.

LIEBERSON, Stanley

2004 "Comments on the Use and Utility of QCA." Qualitative Methods 2/2: 13-4.

MARTin, Isaac William

2013 Rich People's Movements: Grassroots Campaigns to Untax the One Percent. Oxford: Oxford University Press.

Marx, Axel, Benoît Rihoux, and Charles Ragin

2014 "The Origins, Development, and Application of Qualitative Comparative Analysis: The first 25 Years.” European Political Science Review 6/1: 115-42.

McAdam, Doug

1996 “Conceptual Origins, Current Problems, Future Directions." In Comparative Perspectives on Social Movements: Political Opportunities, 
Mobilizing Structures, and Cultural Framings, Doug McAdam, John McCarthy, and Mayer N. Zald, eds., 23-40. Cambridge: Cambridge University Press.

1999 Political Process and the Development of Black Insurgency, 1930-1970. Second Edition. Chicago: University of Chicago Press.

McCARThy, John D., and Mayer N. ZALD

1977 "Resource Mobilization and Social Movements: A Partial Theory." American Journal of Sociology 82/6: 1212-41.

McVeigh, Rory

2009 The Rise of the Ku Klux Klan: Right-Wing Movements and National Politics. Minneapolis: University of Minnesota Press.

Meyer, David S.

2004 “Protest and Political Opportunities." Annual Review of Sociology 30: $125-45$.

Meyer, David S., and Debra C. Minkoff

2004 “Conceptualizing Political Opportunity." Social Forces 82/4: 1457-92.

Mudde, Cas

2000 The Ideology of the Extreme Right. Manchester: Manchester University Press.

2017 "Introduction to the Populist Radical Right." In The Populist Radical Right: A Reader, ed. Cas Mudde, 22-35. Routledge.

OANA, Ioana-Elena, and Carsten Q. SchneIDER

2018 SetMethods: An Add-on Package for Advanced QCA. The R Journal 10/1: 507-33.

Oguma Eiji and Yuko Ueno

2003 Iyashi no nashonarizumu (Healing Nationalism). Tokyo: Keio University Press.

RAGIN, Charles C.

2008 Redesigning Social Inquiry: Fuzzy Sets and Beyond. Chicago: The University of Chicago Press.

2009 "Qualitative Comparative Analysis Using Fuzzy Sets (fsQCA).” In Configurational Comparative Methods: Qualitative Comparative Analysis (QCA) and Related Techniques, Benoit Rihoux and Charles Ragin, eds., 87-121. London: SAGE.

SCHNeIder, Carsten Q., and Claudius WAgEmanN

2012 Set-Theoretic Methods for the Social Sciences: A Guide to Qualitative Comparative Analysis. Cambridge: Cambridge University Press.

Skocpol, Theda, and Vanessa Williamson

2012 The Tea Party and the Remaking of Republican Conservatism. Oxford: Oxford University Press. 
58 | JAPANESE POLITICAL SCIENCE REVIEW 5 (2020)

Smith, Jason Matthew

2010 "Does Crime Pay? Issue Ownership, Political Opportunity, and the Populist Right in Western Europe." Comparative Political Studies 43/11: 1471-98.

TANABE Shunsuke

2010 Nashonaru Aidentiti no Kokusai Hikaku (National Identities in a Comparative Perspective). Tokyo: Keio University Press.

TARrow, Sidney

1998 Power in Movement: Social Movements and Contentious Politics. Second edition. Cambridge: Cambridge University Press.

TAwara Yoshifumi

2016 Nihon kaigi no zenbo (Full View of Japan Conference). Tokyo: Kadensha.

Thiem, Alrik, and Adrian DusA

2013 Qualitative Comparative Analysis with R: A User's Guide. New York: Springer.

Tilly, Charles

1978 From Mobilization to Revolution. Boston, MA: Addison-Wesley Publishing.

VAN Dyke, Nella, and Sarah A. Soule

2002 "Structural Social Change and the Mobilizing Effect of Threat: Explaining Levels of Patriot and Militia Organizing in the United States." Social Problems 49/4: 497-520.

YAsUdA Koichi

2012 Netto to Aikoku (Internet and Patriotism). Tokyo: Kodansha. 